Journal of Teacher Education for Sustainability,

vol. 14, no. 1, pp. 39-51, 2012

\title{
THE PRAXIS OF MENTORING: POWER, ORGANISING AND EMANCIPATION
}

\author{
YiShan Lea \\ Central Washington University, the United States of America
}

\begin{abstract}
The purpose of this article is twofold: first, to juxtapose the praxis of mentoring with its domination and, second, to examine the praxis of mentoring. The rationale of the inquiry is based on social reconstructivist principles, recognising that relational structures and human experiences are both productive and reproductive in nature and in effect. The inquiry has pedagogical implications for institutional practices in education and political implications for individual voluntary versus institutional organising. It is potentially counter-hegemonic against the discourse of globalisation inevitability. Overall, the paper investigates the development and socialisation of human agency in institutional and social associations in which the praxis of mentoring intervenes.
\end{abstract}

Key words: mentoring, praxis, teacher education, pedagogy, faculty organising

\section{Introduction}

The Freirean pedagogy of the oppressed, a method of structural analyses of power, agency, social relations and human conditions (Freire, 1970) in educational institutions, guides the discussion of mentoring.

Mentoring is an anthropological phenomenon in which people are engaged in a teaching and learning relationship that is similar to an apprenticeship. Mentoring has been practised through religious teachings and the traditional ritual of oral transmission of knowledge. Furthermore, mentoring is identified as a "salient concept" (Lea, 2011, p. 260), as it is ambiguous and not yet institutionally defined as a concept. Therefore, this investigation can potentially identify an overarching theme or themes by which people organise their universe of being and along which their consciousness is sensitised and in/action is motivated (Freire, 1970).

The author argues for the need for dissent in higher education to counter hegemony and structural domination in light of the political and pedagogical critiques and power analyses in relational associations and institutionalised organisations. Particularly, the analyses in this paper call for the mentoring practice to be reconceptualised in a critical theoretical perspective. Merging the concepts of mentoring and critical pedagogy as one has the potential to transform praxis across academic disciplines and interpersonal and institutional relations. To address the need to reconceptualise the mentoring practice specifically, the discussion 
includes critiques on mentoring reviewed in the literature, analyses the hegemony that structures the formation of mentoring and its human conditions and examines the constraints of teachers and institutional contradictions in education. Furthermore, to radicalise mentoring, a praxis of mentoring is proposed using theoretical examples from Freire's pedagogy of the oppressed (Freire, 1970), Alinsky's community organising principles (Alinsky, 1971), the revolutionary experiences recounted in Guevara's and Castro's narratives (Guevara, 2003, 2007; Beto, 2006; Castro, 2006).

\section{Critiques of mentoring practices}

Mentoring has enchanted many believers, sponsors, participants and practitioners despite the haze that enshrouds its authentic nature (Schein, 1978; Speizer, 1981; Jacobi, 1991). Although the definition of mentoring is still unclear in the literature, according to Colley's (2003) investigations, mentoring in the form of educational and interventional programmes is widely accepted and gains popularity with invested labour, management costs and even institutional funding. However, the significance of mentoring has yet to be attested through systematic documentation. Lea (2011) observes a clear absence of a natural unobtrusive research approach, and the empirical research approach is often adopted with the experimental design of control of variables. The research literature on mentoring is mainly experimentally designed tests and measurements of the effects of pre-programmed practices. They characteristically comprise artificially matching the dyad of the mentor and the mentee, who are a selected few so called proteges or those who need intervention. Lea (2011) believes, contrary to what empirical research can afford, the investigation of mentoring should call for an alternative. The foremost issue is to understand the contexts in which such an association occurs (Lea, 2011). Giroux (1985) has called for intellectualisation of the teaching profession in the institutional structure; this paper, to follow Giroux's example, besides examining the contexts of the profession, will discuss teachers' development in relation to mentoring in educational institutions in the hope to contextualise the need to radicalise not only the intellectuals, but also the mentors.

\section{The teaching profession}

The teaching profession has often been considered noble, as its reward is expected to be intrinsic rather than extrinsic. In that sense, Freire critiques the anti-intellectual perception against the teaching profession, as it is thought to be involved in low skill labour with low economic value; the associated expectation of teachers to behave like cuddling mothers contributes to class and gender prejudices. College graduates from the arts and humanities disciplines are among the lowest earners. The anti-intellectual perception against teachers' competence persists, and teachers' voices are often marginalised. One example of this negative perception is systems that base teachers' accountability on students' performances on high-stakes examinations and subject teachers to carrot-or-stick incentives. The prescribed professional profile 
reveals an array of contradictions in the institutional management, sociocultural expectations and the criticism/critiques of the field of teacher preparation. In addition, the constant trivialisation and fragmentation of teachers' time and labour define their professionalism as a ministerial procedure. It is reported that “... teachers are exposed to virtually permanent tensions from a number of sources - such as discipline and relations with students; the notalways-realistic expectations of principals, parents and students; and the workload" (Semeniuk \& Worrall, 2000, p. 408). Thus, teachers, deprived of an identity, bearing competence and agency, are perceived as anti-intellectual and authority dependent. There is little wonder that educational reform initiatives often exclude teachers from dialogues on reform. The exclusion of teachers' voices implicates the cultural perception that teachers are unimportant in making decisions to sustain the vitality of an institution and incapable of changing structures. Hence, teachers' subjectivities are easily overwritten in the making of policy.

Teachers' professional lives in educational institutions are a rich text of struggles and identity politics, intertwined with assertions or exercises of agency in which the praxis of mentoring awaits discovery. In other words, while scrutinizing teachers' competence, it is necessary to interrogate the human conditions by which our consciousness, humanity and relational associations develop (Clandinin \& Connelly, 1998; Freire, 1998; Nieto, 2003). The experiences of tension, antagonism and suspicion/negation of one's competence are the common narratives of teachers. Semeniuk and Worrall's (2000) teachers' narratives reveal that teachers build lives and careers in the entrenchments of institutions and struggle against the fragmented existence afforded by the institutions. Semeniuk and Worrall (2000) found that "professional development is hampered [further] by the drain placed on teachers' bodies and minds. The tacit assumption that teachers are lifelong learners is thus undermined by the nature of teachers' work" (p. 423).

The teachers' experiences in the instituted mentoring programmes further complicated their teaching lives. They asked, "How can mentoring even begin to alleviate any of these problems?" In their narratives, teachers expressed that they grew professionally and personally in spite of the institutions and the supposedly functioning mentoring programmes. However, teachers have struggled within the institution, in that many self-doubts arise and even suspicions in reaction to institutional pressures and managerial postures opposed to teachers' work. Similarly, Colley (2003), examining mentoring within institutions, urges that the colonial culture embedded in the context first needs to be interrogated, as it conflicts with the interests of the disaffected youth. She (Colley, 2003) found institutionalised mentoring was construed as a form of intervention. Goals to change and modify behaviours manifest as correctional methods, and the results are neither preventive nor advocative; instead, the process has punitive and harmful outcomes. Mentees can easily become victims in a monolithic institution despite their proclaimed good intentions. Without interrogating the dominant narrative of mentoring, the problems are left intact; the mentee's humanity, however, is easily fragmented, and victimisation is internalised.

In light of the complex intersections of the teaching profession and institutional penchants 
for programming in the global context, investigations of mentoring in human development implicate necessary interrogations of the dominant narratives of mentoring in institutions, as Semeniuk and Worrall (2000) and Colley (2003) suggest. The organisation or formation of mentors' and mentees' associations is profoundly contextually and socially motivated and calls for, therefore, an organisational analysis to identify the shaping conditions of such associations. The teachers' narratives confirm that it is imperative to examine the institutional construction of oppression in relation to the development of competence and agency in the teaching profession.

\section{Globalisation and institutionalising epistemology}

To understand issues pertaining to this topic, the discussion on mentoring will turn to globalisation and the actors enlisted as well as spaces of teaching and institutions dominated by the discourse and persuasion of neoliberalism.

Globalisation has manifested through imperialist conquests by which colonial channels have crossed geopolitical borders. Recently, globalisation has transformed into the ideology of neoliberalism. Kellner (1997) generalises several facets of globalisation that have evolved and affected structural integrations/assimilations, transcending the political cultural lines of epistemology into an economical domination in practice and in living spaces.

[s]ome people see globalization as increasing the homogeneity of societies, whereas others see it as increasing the hybridization of cultures and diversity. For still others, globalization is an evolving operation of power by multinational corporations and state power, or the linchpin for environmental action, democratization, and humanization. Some see the concept of globalization as a contemporary ruse to describe the effects of imperialism or modernization; some claim that modernization would open a new "globalization age" that differs from the "modern age"... (Kellner, 1997, p. 365).

The list above may not be exhaustive. Cognizant of globalisation as a historical effect from the imperialist past or a break from the previous epoch into the next, Kellner (1997) reiterates, "capitalist relations of production still structure most social orders and the hegemony of capital is still the structuring force of most dimensions of social life" (p. 31). This definition means that the language of the market dominates the overall political discourse on ways of organising labour, resources, the educational curriculum, issues of urbanisation, wages, employment, patterns of migration and policies regarding borders, drug trafficking routes, crime, violence, turf or survival wars and other related topics. Congruent with Colley's (2003) position on institutionalised educational practices, specifically on mentoring, the underpinnings of inquiries in Marxist critical theories are potentially counter hegemonic to the massive drowning out of voices and agency by the waves of global markets. Following the framework of global structural integration, the discussion of institutionalised educational practices continues.

Neoliberalism conceives of humans as products to supply to the global market to generate capital and profit for multinational corporations. This process demands the internationalisation of curricula in educational institutions to mould generations of labour forces for corpo- 
rate job descriptions. The slogan of going global and acting local propagates a mass system of schooling that should overcome restrictions of time and space to meet cost-efficient labour supplies (Schofer \& Meyer, 2005). A model of banking education has become ever more popular and corporate-friendly. Mentoring and active critical education are positioned in direct contradiction to the neoliberal corporate labour model of education. The en masse model, by which a monologue is delivered from the podium, dictates social relations and authority from a top-down directed voice. The rapid development of online courses in institutional education is observed; the model has fuelled the growth of for-profit colleges, which receive a large quantity of federal student loan money, but produce the largest number of dropouts.

Schofer and Meyer (2005) have found a world-society model of epistemology adopted in higher education and university expansion. The researchers cite European higher education as an example of the merging of domestic and global developments. The "European Higher Education Area" per se was created to establish "common educational definitions, credentials, and standards" (Schofer \& Meyer, 2005, p. 917) in Europe. The plan is a highway created to channel "flows of students, academic subjects, research agendas, and certified personnel [which] are [is] now treated as routine" (Schofer \& Meyer, 2005, p. 917). Levin's (2006) survey confirms the result that "educational erosion" has ensued, as evidenced by more programmes being eliminated, increases in class sizes, and "faculty interactions with students" (p. 76) being reduced.

Globalisation and neoliberalism compel the work of faculty to be more profit-conscious by maintaining competitive institutional production and perpetuating institutional dominance in the limited global market. The institutional agendas to internationalise and globalise education have not only economic implications, but also social relational impacts. There is evidence that, as globalisation intensifies, corporate interests become political interests, while, as Levin (2006) observes, intellectuals are diminished and subordinated to the administrative managerial ranks. Schofer and Meyer (2005) observe that an antagonistic relation manifests through increasing faculty self-allegiance in higher education. The faculty self-allegiance is motivated to maintain the self-determination of meaning and value. Under the capitalist arrangement of labour, a suppressed faculty agency with conceived antagonism signifies a struggle for intellectual autonomy and political dissent to reclaim humanity. In the economic systems of the means of production and their relation to humans, according to Alinsky (1971), the relation between labour and capital has been historically antagonistic; the owners of capital are "enemies" (p. 135) of their workers. In sum, as Kellner (1997), Schofer and Meyer (2005) and Levin (2006) critique neoliberalism as the dominant ideology premised on massive production and maximising profit turns land into factories, communities into market and skilled or unskilled labour into slaves. Neoliberalism feeds the hunger of the minds by announcing. Before addressing how the praxis of mentoring is transformative in life narratives, the following discussion will distinguish various types of teaching to deconstruct the institutionalised mentoring programmes. 


\section{Deconstructing mentoring}

According to Semeniuk and Worrall's (2000) work on teacher development and mentoring, the dominant narratives of mentoring have yet to be challenged. The common assumption is "the belief that mentoring is a set of identifiable skills which can be taught to one group, the mentors, in order to assist a second group, the protégés" (Semeniuk \& Worrall, 2000, p. 410). Mentoring has been largely implemented in the mode of skill transmission through explicit instructions in universities and public schools in the United States and Great Britain (Colley, 2003). Mentoring is also implemented through venues of formal institutional functions. Brown, Davis and McClendon (1999) identify several aspects that are commonly practised, but are confused with mentoring and in need of demystification. They note that a mentor is not a role or title given to a person arbitrarily from an institutional point of view, and it is not an institutional obligation, such as programme advising, serving on a dissertation committee or providing advice for tenure reviews.

Regarding the transmission of skills, Alinsky's (1971) experience from an organisational point of view is that organising human relations with all their contextual factors exceeds the limited number of pages that an operational manual can contain. Most mentoring programmes, however, are created for skill-based and isolated scenarios, including recruitment, training, workshops and one-to-one consultations. Alinsky (1971) related his experience of educating new community organisers. "The qualities we were trying to develop in organisers in the years of attempting to train them included some qualities that in all probability cannot be taught" (Alinsky, 1971, p. 71). He explains further through the following analogy:

If one thinks of an organizer as a highly imaginative and creative architect and engineer then the best we have been able to train on the job were skilled plumbers, electricians, and carpenters, all essential to the building and maintenance of their community structure but incapable of going elsewhere to design and execute a new structure in a new community (Alinsky, 1971, p. 65-65).

Creative and self-organising aspects are often addressed in the organising principles of Alinsky $(1969,1971)$. Barkham (2005) affirms that "the mentee is by no means a passive receiver; if mentoring is successful, it is usually mentee initiated" (p. 342). According to Brown et al. (1999), a common, yet stereotypical practice is the insistence on pairing mentors with mentees of the same race or gender. This practice may appear as a golden rule initially; however, grouping by simplistic race, culture and gender categories is illogical and potentially borders on cultural isolationism.

The imposition of roles and formalised statuses of mentors or mentees as institutional functions depersonalises people involved in a relationship inclined to be intrinsic and organic in its inception. An institutional voice of authority interferes with independent judgment in giving or receiving advice (Raabe \& Beehr, 2003), which is based on mutual trust, respect, confidentiality, empathy, appreciation and intellectual affinity in identity. Attempts to institutionalise mentoring have had to follow internal common structures to function around 
"routines, rules, norms, and structures" (Torres, 2002, p. 371) and to maintain predictability. Similarly, mentoring programmes can inform a mentor's behaviour on the surface, which the mentee can mimic. The tacit knowledge of deep structures falls outside the realm of institutional accountability, regularity and predictability en masse. Meaningful mentoring has a receptive and sustaining influence on the mentee's growth through life, rather than encouraging the mastery of specific skills on a timeline.

The idea of mentor originates in Homer's Odyssey; a man named Mentor is entrusted by Odysseus to guide his son during his absence. Thus, a mentor is in place of/like a parent. The literature obscures the word 'mentor' in semantics. A mentor is like a nurturer, counsellor, coach, teacher, a role model, a professional colleague, a friend, a sponsor, a protector, an advocate and so on (Schein, 1978; Speizer, 1981; Kram, 1985; Andrews, 1987; Neal, 1992; Caldwell \& Carter, 1993; Barrett, 2000; Roberts, 2000; Beyene, Anglin, Sanchez, \& Ballou, 2002; Tang \& Choi, 2005; Cobb et al., 2006; Paglis, Green, \& Bauer, 2006).

Finding it problematic that the investigation has been on an ever-expanding turf and the claim in a mentor becomes inflated to be superhuman-like, the author proposes to test the logic of the definitions provided in the literature: If it is true that a mentor is like a teacher, then is a teacher a mentor? If a mentor is like a counsellor, is a counsellor a mentor? Through Plato's epistemological model of inquiry that distinguishes appearance from reality, we know that the impersonators of Elvis Presley are not the same as the King of Rock ' $n$ ' Roll. The mentor's true nature and the praxis of mentoring have yet to be discovered amidst the ambiguity of semantics. Plato's epistemology is a philosophical announcement on changing realities and worldviews: through his epistemological inquiries on seeing and the mind itself, seeing the light in its deep structure is derived from struggles against and liberations from hegemony. In addition, Lea (2011) proposes Freire's pedagogy of the oppressed (Freire 1970) as a theoretical lens to analyse the development of a critical consciousness. Hence, seeing the light involves the development of a critical consciousness to distinguish the realities that are projected as shadows or distorted due to asymmetrical power structures, superstitions or fear.

Human development undergoes rites of passage of cultural and discernible changes. Beyond universal biological maturation people grow through experiences and awaken consciousness when they see themselves and their world through the critical distance of multiple perspectives (Freire, 1998). Hence, a mentor mirrors a historical possibility for the mentee. The connection represents a sense of historicity through the distance the mentor has travelled and struggled, and the novice mentee will also travel to grow. Mentors are predecessors in history, particularly to the mentees. According to Barrett (2000), we can find "examples of mentor and mentee [that] include Freud and Jung, Lorenzo de Medici and Michelangelo, Hayden and Beethoven, Boas and Mead, and Sartre and de Beauvoir" (p. 33). It is also wellknown that Socrates was both a mentor and a teacher to Plato. According to Plato's allegory of the cave, the man who returns to the cave to share the truths/experiences of seeing the light is enlightened. Plato (2009) discusses truth and ethics:

the prison-house is the world of sight ... in the world of knowledge the idea of good ap- 
pears last of all and is seen only with an effort; and, when seen, is also inferred to be the universal author of all things beautiful and right, parent of light and of the lord of light in this visible world, and the immediate source of reason and truth in the intellectual; and that this is the power upon which he who would act rationally, either in public or private life, must have his eye fixed ( $p$. 159).

Teaching people to free themselves from "the prison-house" is the mentor's ethical obligation; however, the act of teaching is not without political consequences, as such teaching is subversive and threatening to hegemony. Influenced by the example of Socrates' life, Plato's allegory thus describes the risk of teaching to assist people's liberation:

and if any one tried to loose another and lead him up to the light, let them only catch the offender, and they would put him to death.

No question, he said (Plato, 2009, p. 159).

It is said that those who are bold possess genius, power and magic and dare to speak truth to power, as many critical theorists, scholars, practitioners and activists attempt to do. These great minds have continual contact and daily interactions with people from all walks of life and include learners, cynics or even idealists of all kinds. To mentor is to organise power through relationships, and, by mentoring, one comes to confront him/herself by one's own praxis of coherence, not only discourse.

\section{Organising tactics and organising power}

Maybe all men and women ponder the meaning of life; but some, for good historical reasons, are driven to ponder it more urgently than others (Eagleton, 2007, as cited in Kreber, 2010, p. 18).

Not by chance or by selection, the relationship between the mentor and the mentee is a matter of organising when timing and location intersect and merge. Readiness is crucial for bringing the two dimensions in communion within the temporal and spatial continuum. This concept is similar to the common expression 'being at the right place at the right time', which captures the convergence of historical events and kindred spirits. Organising grows from the grass roots among discontented people, the oppressed and agents of change.

Alinsky (1971) confirms that "change comes from power, and power comes from organisation. In order to act, people must get together. [Hence] power is the reason for being of organizations" (p. 113). To organise mentoring is to organise the power of change, however latent, that flows as life streams in the mentor and the mentee. It is natural and common in political and social life for people to band together for shared interests, agreement or common life experiences, even in situations of deprivation. Alinsky (1971) elaborates as follows:

When people agree on certain religious ideas and want the power to propagate their faith, they organize and call it a church. When people agree on certain political ideas and want the power to put them into practice, they organize and call it a political party. The same 
reason holds across the board. Power and organization are one and the same (p. 113).

Power and organising are complementary, as critical consciousness has its history. People's clarity on the absolute necessity of change builds up over and converges the course of the journey that people decide to take. Conscious people see their historical possibility in events and the manifested "correlation of forces in the world, will determine the mode of action" (Guevara, 2003, p. 75), such as, for instance, its size or form that bonds the complements.

The organisation of power affords a location, a space and an advantageous position from which to confront the obese machinery of hegemony. The Cuban revolutionary experience offers historical testimony on organising forms and the advantages of tactics in a guerilla fight against a well-equipped and trained army. Castro explained the main reason for the Cubans' victory in the Bay of Pigs invasion by the United States and in leading the Cuban revolution "irregular warfare cannot be fought with conventional troops. They're only good for parades. We made an irregular warfare and triumphed over traditional warfare” (Stone, 2004).

Guevara (2007) warns of engaging power in a small size, that a disciplined, vigilant and developed critical consciousness is necessary for the struggles to be fluid and ever responsive. During the Cuban revolutionary war against the Batista army, the organisation of guerillas was small. Its revolution's success came from the emphasis on the guerillas' clarity concerning the reason for fighting and a reasoned lucid militancy on how to fight and persevere (Beto, 2006; Castro, 2006, 2010; Guevara, 2007).

Mentoring practice shares conceptual similarities in organising a rebel army and community organising. Mentoring is a voluntary form of organisation. The particularities of this organisation discussed above include tactical values of size, location and available resources that provide space for dialogues, for resistance and for reclaiming power and humanity. The praxis of mentoring that transforms people's life narratives engages the novice in deliberate perspectives of consideration, construction and deconstruction of power through action. The organising of mentoring conceptually resembles the organising tactics used to counter a larger enemy and is similar to the example of conducting guerrilla warfare in the jungle of hegemony. In our era dominated by the totalising neoliberal economic occupation of land and markets, the struggles we face are urgent and have shifted from "the political terrain to the terrain of mobilisation ... in the streets, in the universities, the factories, in the fields of the world where each one of us reproduces this battle, fights it and wins it or loses it" (Mar$\cos , 2008)$.

\section{The praxis of mentoring: Humanisation, consciousness and the solidarity of struggle}

[T] o be a good liberating educator, you need above all to have faith in human beings. You need to love. You must be convinced that the fundamental effort of education is to help with the liberation of people, never their domestication. You must be convinced that when people reflect on their domination they begin a first step in changing their relationship to the world (Freire, 1971, p. 62). 
According to Issa's (2007) study of mobilisation in Brazil's landless rural workers' movement, the authentic transformation of identity combines the practices for political socialisation with the development of relationships. Organising power for mobilisation first needs to reclaim people's humanity to counter hegemony, as people's humanity endures the foremost assault from oppression and injustice. Hence, the task of the pedagogy of the oppressed is humanisation (Freire, 1970) as the prime motivation for people to free themselves by breaking out of a history of dehumanisation and internalised oppression. The mentor and his/her humanity mirror who and what the mentee will aspire to become. The inherent motivation for struggles is psychological and emotional for one to conspire for humanisation, as in mentoring, community organising, labour worker mobilising or political revolution, albeit in its tactical organising form. Guevara (2007) had dared yet almost struggled to utter "[a]t the risk of sounding ridiculous, let me say that, the true revolutionary is guided by great feelings of love" (p. 225). The mentorship evolves owing to the feelings of love. The mentor and the mentee organise themselves for a shared narrative of struggle, idealism and the necessity to survive, to continue to fight, to triumph and to humanise their world (Guevara, 2007).

Freire's theory of conscientisation to raise critical consciousness comprises a complex array of social cognitive activities. In the abstract form of theory - action - reflection, the praxis of mentoring engages the participants in reflection and action by which the mentor and the mentee form a front of solidarity in their political destiny. Grounded in the solidarity of multiplicity, mentoring is structured pedagogically through dialogues to influence and assist the mentee's act of transformation. The mentor/mentee connection helps to humanise people's worlds through relationships; mentoring also awakens the mentee's world consciousness. Alinsky (1971) noted that the conscious awakening of the relationship between the self and the world is existentially significant, as people experience themselves as the organisers of relations, power and actions. Hence, mentoring is a direct contradiction to a universe of silence, apathy, passivity and inaction. Alinsky (1971) has likened this awakening of consciousness to rousing waves and breaking silence in the oppressive sea of the existential "quiet desperation" (p. 116).

Mentoring is the praxis of solidarity in which the personal and the social dimensions merge. While the former refers to the personally active practice of theory - action - reflection, the latter involves a dialectical engagement of the mentor and the mentee confronting shared human conditions, knowing that to struggle is necessary and to survive is interdependent. By participating in or witnessing acts of resistance, the mentee vicariously experiences a taste of freedom and power in sharing and investing in emotional labour and costs. Simultaneously, the mentor and the mentee share similar agency at a crucial point in time.

Liberation, agency and humanism are the manifestations of solidarity that social reformers, "organic intellectuals" (Gramsci, 2010, p. 5) and the oppressed come to share. Guevara (2003) proposed "[However], where do we find the great [teachers/mentors]?" (p. 75). He (Guevara, 2003) declared that "like any other human being, they are the product[s] of history" (p. 75). Great mentors or community organisers, regardless of whether their roles merge, will 
travel and forge their own paths, and they will learn the praxis. In the case of mentoring, in its own globalised neoliberal context, struggle itself is the greatest teacher for understanding the need to organise, connect and educate.

Mentoring is a response to the conditions of domination against the hegemonic narrative of globalisation. Through organising, agency and solidarity are awakened with respect to power, identity and world humanisation. Hence, the praxis of mentoring is pedagogical, and its organisation implicates organic constructions of power and space against totalising acts of neoliberal annihilation. Solidarity does not merely serve good intentions and is not simply "a matter of wishing success to the victims of aggression" (Guevara, 2003, p. 75). For revolutionary or transformative ideas to survive, in this case, the mentor and the mentee are to share each other's fate and learn the art of resistance and struggle. By journeying or fulfilling a shared destiny for emancipation and resistance against global fragmentation and neoliberal disintegration, the torch of idealism will change hands between kindred spirits.

\section{References:}

Alinsky, S. (1971). Rule for radicals: A pragmatic primer for realistic radicals. New York, NY: Vintage Books.

Andrews, I. (1987). Induction program: Staff development opportunities for beginning and experienced teachers. In M. F. Wideen \& I. Andrews (Eds.), Staff development for school improvement: A focus on the teacher (pp. 142-153). New York and Philadelphia: The Falmer Press.

Barkham, J. (2005). Reflections and interpretations on life in academia: A mentee speaks. Mentoring and Tutoring, 13(3), 331-344.

Barrett, T. (2000). Studio critiques of student art: As they are, as they could be with mentoring, Theory into Practice, 39(1), 29-35.

Beto, F. (2006). Fidel and religion: Conversations with Frei Betto on Marxism and liberation theology. NY: Ocean Press.

Beyene, T. M., Anglin, W., Sanchez, Z., \& Ballou, M. (2002). Mentoring and relational mutuality: Proteges' perspectives. The Journal of Humanistic Education and Development, 41(1), 87-102.

Brown, M. C., Davis, G. L., \& McClendon, S. A. (1999). Mentoring graduate students of color: Myths, models, and modes. Peabody Journal of Education, 74(2), 105-118.

Caldwell, B. J., \& Cater, E. M. A. (Eds.). (1993). The return of mentor: Strategies for workplace learning. London and Washington, DC: The Falmer Press.

Castro, F. (2006). Che: A memoir by Fidel Castro. NY: Ocean Press.

Castro, F. (2010, January 27). Fidel Castro in his own words [Video file]. Retrieved June 20, 2012, from http://www.youtube.com/watch?v=67ZWBl-66H8

Clandinin, D. J., \& Connelly, F. M. (1998). Stories to live by: Narrative understandings of 
school reform. Curriculum Inquiry, 28(2), 149-164.

Cobb, M., Fox, D. L., Many, J. E., Matthews, R. W., McGrail, E., Tinker Sachs, G., \& Colley, H. (2002). A 'rough guide' to the history of mentoring from a Marxist feminist perspective. Journal of Education for Teaching: International. Research and Pedagogy, 28(3), 257-273.

Colley, H. (2003). Engagement mentoring for 'disaffected' youth: A new model of mentoring for social inclusion. British Educational Research Journal, 29(4), 521-542.

Eagleton, T. (2007). The meaning of life: A very short introduction. Oxford: Oxford University Press.

Freire, P. (1970). Pedagogy of the oppressed. New York: Continuum.

Freire, P. (1971). To the coordinator of a cultural circle. Convergence, 4(1), 61-62.

Freire, P. (1998). Teachers as cultural workers. Colorado: Westview Press.

Giroux, H. (1985). Teachers as transformative intellectuals. Social Education, 5, 376-379.

Guevara, E. C. (2003). Che Guevara reader. Melbourne, Australia: Ocean Press.

Guevara, E. C. (2007). Guerrilla warfare. US: BN Publishing.

Gramsci, A. (2010). Selections from the prison notebooks. New York: International Publisher.

Issa, D. (2007). Praxis of empowerment: Mistica and mobilization in Brazil's landless rural workers' movement. Latin American Perspectives, 34(2), 124-138.

Jacobi, M. (1991). Mentoring and undergraduate academic success. A Literature Review. Review of Educational Research, 61(4), 505-532.

Kellner, D. (1997). Globalization and the post-modern turn. Available from http//www.gseis. ucla.edu/courses

Kram, K. (1985). Mentoring at work: Developmental relationships in organizational life. Glenview, IL: Scott, Foresman.

Kreber, C. (2010). Courage and compassion in the striving for authenticity: States of complacency, compliance, and contestation. Adult Education Quarterly, 60(2), 177-198.

Lea, Y. (2011). On mentoring: When the student is ready, the teacher will appear. The International Journal of Learning, 18(1), 259-268.

Levin, J. S. (2006). Faculty work: Tensions between educational and economic values. The Journal of Higher Education, 77(1), 62-88.

Marcos. (2008, August 17). Subcomandante Marcos Interview 3/3 [Videofile]. Retrieved June 20, 2012, from http://www.youtube.com/watch?v=PMRyPnQGRks\&NR=1\&feature=end screen

Neal, J. C. (1992). Mentoring: A teacher development activity that avoids formal evaluation of the protégé. In T. M. Bey \& C. T. Holmes (Eds.), Mentoring: Contemporary principles and issues (pp. 35-49). Reston, VA: Association of Teacher Educators.

Nieto, S. (2003). What keeps teachers going? NY: Teachers' College Press. 
Paglis, L., Green, S., \& Bauer, T. (2006). Does adviser mentoring add value? A longitudinal study of mentoring and doctoral student outcomes. Research in Higher Education, 47(4), $451-476$.

Plato. (2009). The republic. (Benjamin Jovett, Trans.). Available from http://classics.mit.edu/ Plato/republic.html.mit.edu/Plato/republic.html.

Raabe, B., \& Beehr, T. (2003). Formal mentoring versus supervisor and co-worker relationships: Differences in perceptions and impact. Journal of Organizational Behavior, 24, 271-293.

Roberts, A. (2000). Mentoring revisited: A phenomenological reading of the literature. Mentoring \& Tutoring, 8(2), 145-170.

Schein, E. H. (1978). Career dynamics: Matching individual and organizational needs. Reading, MA: Addison-Wesley.

Schofer, E., \& Meyer, J. (2005). The worldwide expansion of higher education in the twentieth century. American Sociological Review, 70, 898-920.

Semeniuk, A., \& Worrall, A. (2000). Rereading the dominant narrative of mentoring. Curriculum Inquiry, 30(4), 405-428.

Speizer, J. L. (1981). Role models, mentors, and sponsors. Signs, 6(4), 692-712.

Stone, O. (Director). (2004). Comandante [Documentary]. Los Angeles, CA: Media Production.

Tang, S. Y. F., \& Choi, P. L. (2005). Connecting theory and practice in mentor preparation: Mentoring for the improvement of teaching and learning. Mentoring and Tutoring, 13(3), $383-401$.

Taylor, D. L., Wallace, F. H., \& Wang, Y. (2006). Mentoring in literacy education: A commentary from graduate students, untenured professors, and tenured professors. Mentoring and Tutoring, 14(4), 371-387.

Torres, C. A. (2002). Globalization, education, and citizenship: Solidarity versus markets? American Educational Research Journal, 39(2), 363-378.

\section{Correspondence:}

YiShan Lea, Ed.D., Assistant Professor of Bilingual Education, Central Washington University, 400 E. University Way, College of Education, Ellensburg, WA 98926, USA. Email: leayishan@hotmail.com 